Review

\title{
A Current Review of Social Impact Assessment on Sustainable Biomass/Biofuel Development
}

\author{
Shinichirou MORIMOTO, and Koichi MIYAMOTO
}

(Received June 19, 2008)

\begin{abstract}
持続可能なバイオマス・バイオ燃料開発における社会影響評価の現状と動向 森本慎一郎, 宮本耕一
\end{abstract}

\begin{abstract}
Global production of biomass and biofuel are growing rapidly, due to the increases in the price of fossil fuels, growing environmental concerns, and considerations regarding the security and diversification of energy supply. However, the production of biomass energy crops and removal of biomass residues from forest and agricultural systems for energy production can result negative environmental, economical, or social impact. Therefore, sustainable development of biomass and biofuel are the major issue in order to increase the production of biomass and biofuel.

This paper aims to review the current assessment study on sustainable development of biomass and biofuel, especially about social impact which is not widely known comparing with environmental and economical impact. Furthermore, the key factor of social impact assessment on sustainable biomass and biofuel development is analyzed in order to apply the result of assessment for development of biomass and biofuel certification and planning of energy policy.
\end{abstract}

\section{Key Words}

Biomass, Biofuel, Sustainable development, Social impact assessment, Bio-ethanol, Bio-diesel fuel

\section{1. 序 論}

近年，世界各国ではエネルギー安定確保，及び温室効 果ガス削減を目的としてバイオマス・バイオ燃料の導入 が急速に加速しており，我が国においても2006年にバイ オマスニッポン総合戦略1) が策定され，バイオマス・バ イオ燃料導入に向けた具体的な導入目標值とアクション プランが設定されている（なお，バイオマスとは家畜排 泄物，生ゴミ，及び木くずなどの動植物から生まれた再 生可能な有機性資源を意味し，バイオ燃料とはそれら有 機性資源から製造されたバイオエタノール等の液体燃料 を意味する)。これら，バイオマス・バイオ燃料の導入促 進においては食料との競合や環境破壊など多くの課題が 付随・関連するため, それらの課題解決を目指した“持 続可能なバイオマス・バイオ燃料の開発”が重要との認 識が近年，世界的に高まりつつある。

そうした中，“持続可能な開発”については現在，国際

National Institute of Advanced Industrial Science and

Technology

Umezono1-1-1Central2, Tsukuba-shi, Ibaraki 305-8568, Japan
的な枠組みでの議論が活発化しており（例えば国連経済 社会局持続可能開発部における持続可能な開発委員会 (CSD : Commission on Sustainable Development) ${ }^{2)}$ の設立 など), 持続可能なバイオマス・バイオ燃料開発において もこうした国際的議論での評価枠組みや設定基準を適用 する傾向が多く見られる。また，それら評価枠組みや設 定基準の適用範囲についても，政策への適用から具体的 な研究開発戦略への適用など, その適用範囲は様々と なっている。

一般的に “持続可能な開発”における評価指標は “環 境影響” “経済影響” “社会影響”の3つに分けられてい る ${ }^{3)}$ 。それら評価指標の中で “環境影響” と “経済影響” については上述した政策や研究開発戦略への適用方法に ついて世界的に広く認知されているが，相対的に“社会 影響” 評価については適用方法や適用事例について広く 認知されていない。バイオマス・バイオ燃料の導入を促

(独) 産業技術総合研究所
T 305-8568
茨城県つくば市梅園 1-1-1つくば中央第二


進している我が国としても，持続可能なバイオマス・バ イオ燃料開発に打ける社会影響評価の現状を包括的に調 查し，政策や研究開発戦略への適用方法とあり方につい て検討することは今後，重要な課題となる。

そこで本論文では持続可能なバイオマス・バイオ燃料 開発に抢ける社会影響評価について，その評価範囲，評 価指標，及び評価方法を包括的に調査し，それらの現状 と動向について分析すると共に社会影響評価の（基準設 定など）政策や研究開発戦略への適用状況について類型 化を行う。さらにその結果を踏まえ，持続可能なバイオ マス・バイオ燃料開発における社会影響評価を政策や研 究開発戦略へ適用する上での課題を導出し, 明らかにす ることを目的とする。

\section{2. 調査事例の概要と類型化}

本章ではこれまでの持続可能なバイオマス・バイオ燃 料開発に打ける社会影響評価を行った事例の調査結果と 動向分析結果，さらにそれら社会影響評価の適用状況に 関する類型化と分析の結果を記述する。

\section{1 調査事例の概要}

\subsection{1 持続可能なバイオマス・バイオ燃料開発におけ る社会影響評価の現状}

バイオマス・バイオ燃料についてはエネルギー安定確 保，及び温暖化対策として近年，急速に導入が促進され て抢り，各国ではその導入に向けて具体的な目標值とア クションプランを策定している。しかし，バイオマス・バ イオ燃料導入に打いてはエネルギー作物の増産，バイオ マス残渣を農業・林業システムから除去することによる 悪影響，土地利用パターンの変更，及び社会経済的なイ ンパクトなど多くの課題があり，そのためバイオマス・バ イオ燃料の開発に扔いても “持続可能な開発”が必要で あるとの認識が現在，世界的に高まっており，これまで 様々な国際機関，国家，及び地域で持続可能なバイオマ ス・バイオ燃料開発についての検討が行われている。

ここで，持続可能なバイオマス・バイオ燃料開発にお ける社会影響評価とはバイオマス・バイオ燃料の生産，も しくはその利用によって生じる社会的な影響の評価を意 味しており, 具体的評価指標としては例えばCSDで提案 されている通り，バイオマス・バイオ燃料開発によって 生じる世帯当たりの収入や賃金の変化, 生活環境の改善, 健康への影響，教育水準への影響等などがある3)。これま で持続可能なバイオマス・バイオ燃料開発に関する社会 影響評価のあり方については国連エネルギー（UN Energy）に抢ける報告書 “Sustainable Bioenergy：A Framework for decision makers” ${ }^{4)}$ や国際エネルギー機関 (IEA : International Energy Agency) バイオエネルギータ スク 295) 等で検討されており, 社会影響評価の具体的な
評価範囲，評価指標，評価方法について検討されている。 こうした社会影響評価の評価結果は, 現状把握に基づ く基準設定の検討など政策に適用されるのが通常である が，持続可能なバイオマス・バイオ燃料開発における社 会影響評価に関しては，現状ではそうした基準設定（以 下，本論文では賃金や生活環境など社会影響を考慮した 基準を “社会基準” 記す）への適用事例は見当たらな い。そのため, 持続可能なバイオマス. バイオ燃料開発 における社会基準の検討はバイオエネルギータスク 406) での検討，及び東南アジアを中心とした持続可能なパー ム油のための円卓会議 (RSPO : Roundtable on Sustainable Palm $\left.\mathrm{Oil}^{77}\right)$ などのように, 社会影響評価結果の適用とい う概念では検討が行われていない。その場合, 社会基準設 定は国際労働機関 (ILO:International Labour Organization) 基準 ${ }^{8)}$ など既存の基準を参考にしているケースが大部分 となっている。

\subsection{2 持続可能なバイオマス・バイオ燃料開発におけ る社会影響評価事例}

本節では持続可能なバイオマス・バイオ燃料開発にお ける社会影響評価事例について, 国家・地域単位, 及び 国際機関·国際的組織に分けてその概要を述べる。なお， 持続可能なバイオマス・バイオ燃料開発に打ける社会基 準設定の検討については上述した通り社会影響評価結果 の適用という概念で検討が行われていないが，社会影響 評価の現状を把握する上で参考になるものと考元，本論 文に打いては社会影響評価事例同様に事例の説明を行う。

(1) 国家・地域単位での検討事例

持続可能なバイオマス・バイオ燃料開発に扔ける国家・ 地域単位での社会影響評価事例について, 表 1 にその概 要を示す。

表 1 に示す通り，国家・地域単位では米国，オランダ, オーストラリア，イギリス，及びドイッ等，先進国を中 心に持続可能なバイオマス・バイオ燃料開発における社 会影響評価検討が行われて打り，その他では唯一ブラジ ルがバイオ燃料の大量導入国として検討を進めている。 これら各国の中でオランダ，ドイッ，及びイギリス等は 特に持続可能なバイオマス・バイオ燃料開発に扔ける社 会基準設定に向けた検討が中心となっているが，実際の 基準設定・導入にまで至っているのはイギリスのRTFOの みで，その他は各国の基準設定のあり方について提言さ れるまでにとどまっている。他方，米国，オーストラリ ア，及びブラジルでは持続可能なバイオマス・バイオ燃 料開発における社会影響評価に向けた検討が行われてい るが，評価結果の具体的適用方法までは検討されていな い。これらはいずれも過去 5 年以内に行われた検討であ り，基準の設定・導入，もしくは評価結果の適用につい ては未だ多くの課題を残した状況となっている。 
表 1 国家・地域単位での検討事例

\begin{tabular}{|c|c|c|}
\hline 組織名（国名・年） & 評価·基準指標 & 事例概要 \\
\hline Embrapa（ブラジル・2007） & $\begin{array}{l}\text { ·雇用創出比率, 技術力養成比率 } \\
\text { ·賃金, 収入, 地価への影響 } \\
\cdot \text { 健康と安全性（治安）への影響 } \\
\cdot \text { 廃裹物処理・施設等への影響 }\end{array}$ & $\begin{array}{l}\text { ブラジル農林水産省の農作物研究機関Embrapaがブラジル } \\
\text { における } 5 つ \text { 归でBDF燃料導入に関する社会環境影響評 } \\
\text { 価を行った研究事例。持続性評価については言及されてい } \\
\text { ないが, 社会性影響評価については, 各評価指標の重み付 } \\
\text { けも含めて詳細な評価を行っている }\end{array}$ \\
\hline $\begin{array}{l}\text { SIBR: Socioeconomic Impacts of } \\
\text { the Biofuels Revolution（米国 · } \\
\text { 2007） }\end{array}$ & 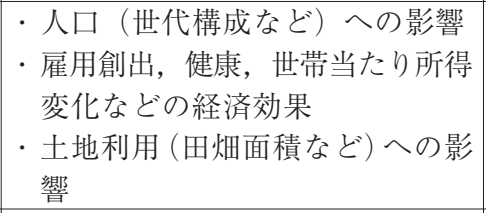 & $\begin{array}{l}\text { 米国カンサス州立大学で“バイオ燃料導入における社会経 } \\
\text { 済評価プロジェクトかが行われ，同州におけるバイオ燃料 } \\
\text { 導入による社会経済性影響評価を行った。州立機関のデー } \\
\text { 夕収集を中心とした調査を行なっており，重み付け等は } \\
\text { 行っていない }\end{array}$ \\
\hline $\begin{array}{l}\text { CEC : California Energy Com- } \\
\text { mission (米国 } \cdot 2006)\end{array}$ & $\begin{array}{l}\text { ·教育水準や技術の向上 } \\
\text { ・企業や州立機関など地域社会の } \\
\text { 充実 } \\
\text { ・教育プログラムの策定と実施 } \\
\text { ·資金や運営に関する組織連携の } \\
\text { 実施 }\end{array}$ & $\begin{array}{l}\text { 米国カリフォルニア州はバイオエネルギー導入に関する具 } \\
\text { 体的な目標值を設定し，それに向けたアクションプラン } \\
\text { してバイオエネルギー導入に向けた研究開発ロードマップ } \\
\text { の作成を行った。作成されたロードマップの中には社会性 } \\
\text { に関する項目も検討されている }{ }^{11)} \text { 。 }\end{array}$ \\
\hline $\begin{array}{l}\text { Utrecht University（オランダ・ } \\
\text { 2006） }\end{array}$ & $\begin{array}{l}\text { 食料との競合，雇用創出，所得と土 } \\
\text { 地利用，賃金，労働条件(労働環境) } \\
\text { 等 }\end{array}$ & $\begin{array}{l}\text { ブラジル (サンパウロ市) のバイオエタノール導入におけ } \\
\text { る影響と適用されている持続性評価・基準の現状を調査 } \\
\text { し, それに対してオランダの持続性評価・基準の現状との } \\
\text { 比較を行い, 実際にオランダの持続性評価・基準をブラジ } \\
\text { ルに導入した場合, 想定される費用とボトルネックを評価 } \\
\text { した }{ }^{12)} \text { 。 }\end{array}$ \\
\hline $\begin{array}{l}\text { RIRDC : Rural Industries Re- } \\
\text { search and Development Corpo- } \\
\text { ration (オーストラリア・2005) }\end{array}$ & $\begin{array}{l}\text { ·雇用創出比率, 技術力養成比率 } \\
\text { - 健康と安全性 (治安) への影響 } \\
\text { ·公共設備と景観への影響 } \\
\text { ·地域・国・地球規模での産業・経 } \\
\quad \text { 済への影響評価 }\end{array}$ & $\begin{array}{l}\text { オーストラリアにおけるバイオエネルギー開発に関する持 } \\
\text { 続性評価フレームワーク構築を行った。持続性評価項目と } \\
\text { しては主に経済影響, 環境影響, 社会影響の } 3 \text { つが挙げら } \\
\text { れており, それらについ扎搷体的な評価方法及び評価指標 } \\
\text { について検討が行われた }{ }^{13)} \text { 。 }\end{array}$ \\
\hline $\begin{array}{l}\text { RTFO : Renewable Transport } \\
\text { Fuel Obligation（イギリス・ } \\
\text { 2007） }\end{array}$ & \begin{tabular}{|l|} 
労働条件，児童雇用，健康と安全， \\
人種差別，賃金など
\end{tabular} & 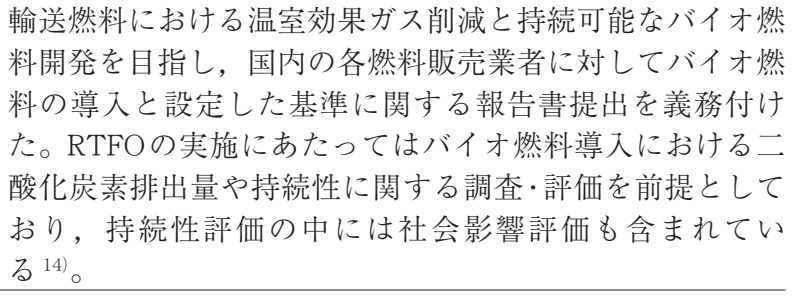 \\
\hline $\begin{array}{l}\text { WWWF : World Wide Fund for } \\
\text { Nature（ドイツ・2006） }\end{array}$ & $\begin{array}{l}\text { ・労働条件 (賃金, 不法な重労働, } \\
\text { 未成年の雇用) など } \\
\text { ・健康被害(健康被害の削減, 農作 } \\
\text { 業に拈ける安全性確保) }\end{array}$ & $\begin{array}{l}\text { バイオエネルギー開発における環境・社会影響評価を包括 } \\
\text { 的にレビューし，将来の持続可能なバイオエネルギー開発 } \\
\text { を行うための基準について検討を行った }{ }^{15)} \text { 。 }\end{array}$ \\
\hline
\end{tabular}

そうした中，表 1 に示した事例の中で特に定量評価を 含んだ社会影響評価を行うなど相対的に検討が進展して いる事例はブラジル ${ }^{9)}$ ，及びオランダの事例 ${ }^{12)}$ と考えら れる。

ブラジル農林水産省管轄の農作物研究機関 Embrapa で はブラジルにおける 5 つの州で 4 通りの原料を想定した $\mathrm{BDF}$ 燃料導入に関する社会環境影響評価を行った。社会 影響評価指標としては 14 の評価指標が検討されており, 環境影響評価指標と合わせると合計 240 評価指標が設定 されている。社会影響評価手法としては，フィールド調 査，および関係者へのインタビュー調査を行なうことで 上記各評価指標について定量的なデー夕を収集し，それ ら収集したデータについて BDF導入前後における変化率
を算出している。さらに各評価指標の重み付けを行い, そ れと各評価指標の変化率とから最終的に土15の統合評価 指標によって BDF 燃料導入における影響を評価してい る。研究結果では, 評価したいずれの州も社会影響の観 点からは改善・増加がみられたものの, 環境影響につい てはいくつかの評価指標について悪化・減少が見られた と述べている ${ }^{9)}$ 。

またオランダでは Utrecht 大学とブラジル Campinas 大 学が共同でブラジルのバイオエタノール導入における持 続性評価を行っており，この持続性評価の中には雇用創 出など社会影響評価も含まれている。この評価の目的は 現状で議論されている持続性評価指標を基に設定した各 社会影響評価指標について，ブラジル(サンパウロ市)の 
バイオエタノール導入における影響を定量的に調査し， さらにオランダの持続可能性に関連する基準を実際にブ ラジルに導入した場合の各社会影響評価指標への影響を 定量的に評価することで基準導入による費用とボトル ネックを分析するというものである。社会影響評価指標 としては雇用創出や所得・賃金など定量的にデータ収集 が可能な評価指標を想定しており，それら各評価指標に ついてオランダの基準をブラジルに適用することを想定
してその影響を定量的に評価した結果，ブラジルのバイ オエタノール価格は現状よりも5 6 \% 増大することを明ら かにしている。

(2) 国際機関・国際的組織での検討事例

持続可能なバイオマス・バイオ燃料開発における国際 機関・国際的組織での社会影響評価事例について，表 2 にその概要を示す。

表 2 に示すとおり，これまで持続可能なバイオマス・バ

\section{表 2 国際機関・国際的組織での検討事例}

\begin{tabular}{|c|c|c|}
\hline 組織名（年） & 評価·基準指標 & 事例概要 \\
\hline $\begin{array}{l}\text { UN Energy } \\
(2007)\end{array}$ & $\begin{array}{l}\text { ·貧困階層へのエネルギー供給ポ } \\
\text { テンシャル } \\
\text { ·農産業開発と雇用創出への影響 } \\
\text { ·健康, 男女差への影響 } \\
\text { ·食料安全保障への影響 }\end{array}$ & $\begin{array}{l}\text { バイオエネルギー開発における大小規模の社会, 経済, 環 } \\
\text { 境から見た持続性評価のあり方について検討を行った。こ } \\
\text { れは持続的開発可能な社会に向けたバイオエネルギー導入 } \\
\text { に関するる政策策定に資する情報を提供するもので, バイオ } \\
\text { マスの適用範囲としては液体バイオ燃料, バイオガス, 固 } \\
\text { 体燃料としてのバイオマスとしている }\end{array}$ \\
\hline $\begin{array}{l}\text { IBEP : International Bioenergy } \\
\text { Platform (2006) }\end{array}$ & $\begin{array}{l}\cdot \text { 土地利用の変化 } \\
\text { ·貧困の緩和と生活環境の改善 } \\
\text { ·食料安全保障 }\end{array}$ & $\begin{array}{l}\text { 性別, 富, 地域, 文化等とは無関係に人々がバイオエネル } \\
\text { ギー源に平等にアクセスすることを保証することにより, } \\
\text { 持続可能な開発, エネルギーセキュリティ, 貧困削減等を } \\
\text { サポートするための政策立案, 情報提供を行っている。立 } \\
\text { 案政策の中には社会影響評価のあり方についても提言され } \\
\text { ている }\end{array}$ \\
\hline $\begin{array}{l}\text { FAO : Food and Agriculture } \\
\text { Organization }(2005)\end{array}$ & $\begin{array}{l}\text { ·先住民, 森林居住者の保護 } \\
\text { ·男女差の削減 } \\
\text { ·教育, 技術などの育成 }\end{array}$ & $\begin{array}{l}\text { 森林管理を行うことで森林の利用にあたっての管理的, 法 } \\
\text { 律的, 技術的, 社会的, 環境的等の側面を包含した幅広い } \\
\text { マネジメントを行い, 物資及びサービスの生産と生物多様 } \\
\text { 性, エコシステムの維持の両立について情報提供等を行っ } \\
\text { ている }{ }^{17)} \text { 。 }\end{array}$ \\
\hline $\begin{array}{l}\text { UNDP: United Nations Develop- } \\
\text { ment Programme }(2006)\end{array}$ & $\begin{array}{l}\cdot \text { ·口 (世帯数 }) \text { 変化 } \\
\cdot \text { 雇用創出, 雇用条件の変化, 雇用 } \\
\text { 世代 (年齢) の変化 } \\
\cdot \text { 技術力の養成 }\end{array}$ & $\begin{array}{l}\text { 中国におけるバイオマスプランテーション開発の社会影響 } \\
\text { 評価を行った。持続性評価の一環として詳細な社会影響評 } \\
\text { 価を行っており，設定した評価指標についてフィールド調 } \\
\text { 査を基に詳細な定量評価を行っている }\end{array}$ \\
\hline $\begin{array}{l}\text { IEA : International Energy } \\
\text { Agency-Bioenergy } \text { Task29 } \\
(2005)\end{array}$ & $\begin{array}{l}\text { ·地域の人口構成と持続性 } \\
\text { ·食料・エネルギー安全保障 } \\
\text { · 労働者, 雇用創出 } \\
\text { ·設備建設の増加 } \\
\text { ·収入と貯蓄の増加 }\end{array}$ & $\begin{array}{l}\text { “Socio-Economic Drivers in Implementing Bioenergy Projects” } \\
\text { と題してバイオエネルギー開発に関する地域・国家・国際 } \\
\text { レベルでの社会経済影響評価に関する現状と動向と影響に } \\
\text { 関するサブライチェーン間の関連性分析を行い, ステーク } \\
\text { ホルダーに対して政策決定に資する情報の提供を行ってい } \\
\text { る5)。 }\end{array}$ \\
\hline $\begin{array}{l}\text { IEA : International Energy } \\
\text { Agency-Bioenergy } \text { Task40 } \\
(2006)\end{array}$ & 具体的な指標はなし & $\begin{array}{l}\text { “Overview of recent developments in sustainable biomass } \\
\text { certification” と題してバイオマス・バイオエネルギー開発 } \\
\text { に関する基準や標準設定のあり方について, 様々なステー } \\
\text { クホルダーの検討状況に関する調査と動向分析を行ってい } \\
\text { る。さらに, 基準設定の開発に関する限界と適用の問題点 } \\
\text { について分析を行っている }{ }^{6)}\end{array}$ \\
\hline $\begin{array}{l}\text { GBEP : G8 Global Bioenergy } \\
\text { Partnership (2005) }\end{array}$ & $\begin{array}{l}\cdot \text { 雇用の創出 } \\
\cdot \text { 地域の荒廃を防止と活性化 } \\
\cdot \text { 土壤の劣化防止 } \\
\cdot \text { 廃棄物の有効活用 }\end{array}$ & $\begin{array}{l}\text { G8 各国がバイオマス資源をバイオ燃料の原材料としての } \\
\text { 重要性以外に雇用の創出, 地域の荒廃を防止し活性化, 土 } \\
\text { 壤の劣化防止, 廃衰物の有効活用等の社会·経済的な側面 } \\
\text { からも重視していることから, バイオ燃料の利活用を促進 } \\
\text { するため各国の取組みに加え, 協力体制の構築に向けて国 } \\
\text { 際的な取組みを行っている }{ }^{19) 。}\end{array}$ \\
\hline $\begin{array}{l}\text { RSPO : Roundtable on Sustain- } \\
\text { able Palm Oil }(2001 \sim)\end{array}$ & $\begin{array}{l}\text { ·賃金, 雇用, 児童労働, 労働条件 } \\
\text { ·先住民や地域コミュニティの保 } \\
\text { 護 } \\
\text { 土土地利用 }\end{array}$ & $\begin{array}{l}\text { パーム油に関連する様々なステークホルダーが対話・協力 } \\
\text { し, 世界基準の策定など持続可能なパーム油の開発・利用 } \\
\text { 促進を目指すために国際的枠組みで構築された。これまで } \\
5 \text { 回の円卓会議が開催され, 原則と基準の作成, 開発指標 } \\
\text { の検討が行われた }\end{array}$ \\
\hline
\end{tabular}


イオ燃料開発における社会影響評価については国連を中 心にIEA，及びG8等，様々な国際機関・国際的組織で検 討されている。

しかしながら，国際機関・国際的組織での検討も持続 可能なバイオマス・バイオ燃料開発における社会影響評 価や基準設定のあり方についての包括的な提言にとど まった事例が殆どであり，UNEnergy，IBEP，FAO，IEA， 及び GBEP のいずれも包括的提言，もしくは政策提言に 向けた情報提供が主な目的となっている。またこれらは いずれも国家・地域単位での検討と同様，過去 5 年以内 に行われた検討であり，基準の設定・導入，もしくは評 価結果の適用については未だ多くの課題を残した状況と なっている。

そうした中，表 2 に示した事例の中で特に持続可能な バイオマス・バイオ燃料開発における社会影響評価に関 して定量評価を含んだ詳細な社会影響評価を行った事例 は UNDP の事例であり ${ }^{18)}$ ，中国におけるバイオマスプラ ンテーション開発の社会影響評価を行っている。本事例 はバイオマスの利活用における社会影響評価ではなく, 植林などバイオマスプランテーションにおける社会影響 評価であるが，持続可能性を勘案した詳細な定量的社会 影響評価を行って打り，具体的には中国広西壮族自治区 のバイオマスプランテーション開発プロジェクトについ て専門家チームによるステークホルダーへの質問形式 （アンケート方式）を基本としたフィールドワーク調査に より社会影響を定量的に評価している。社会影響評価指 標としては同プロジェクトに関連する人口変化，雇用創 出，所得変化などを中心としており，具体的には同プロ ジェクトに土地を提供している人口 (世帯数) の変化率, 同プロジェクトに関与している雇用者数変化率，及び雇 用者の所得変化率をインタビュー形式で調查し，また雇 用者変化率についても具体的な業務内容，雇用者年齢，獲 得技術，及び雇用条件などの実態について調査している。

また表 2 の事例の中で持続可能なバイオマス・バイオ 燃料開発に扮ける社会基準設定で相対的に最も検討が進 展している事例はRSPO であると考えられる。RSPO は パーム油に打けるサプライチェーン間での協力とステー クホルダー間の対話を通じて持続可能なパーム油の成長 と利用を促進するため，信頼のおける世界基準の策定，実 施，及び検証を目的としている。2007年11月には第 5 回 円卓会議が開催され，持続可能なパーム油を促進するた めの原則と基準について, 承認と認証フレークワーク構 築まで完了している。これら原則と基準の中には社会影 響に関する項目として賃金や労働条件など雇用に関する 項目や先住民や地域コミュニティの保護に関する項目も 含まれている。

\section{2 調査事例の類型化}

本節では表 1 ～2 に示した事例について持続可能なバ イオマス・バイオ燃料開発における社会影響評価の（基 準設定など）政策や研究開発戦略への適用状況について 類型化を行う。それによって，現在の適用状況と動向に ついて分析を行う。

事例の類型化については “持続可能なバイオマス・バ イオ燃料開発に関する社会影響評価のあり方”，及び“持 続可能なバイオマス・バイオ燃料開発に関する社会基準 設定のあり方”の 2 通りに大別し，さらにそれぞれにつ いて検討の具体性を基準に 2 通りに分けるものとする。 以上より，本節では事例を以下の 4 類型に類型化する。 類型 1 : 持続可能なバイオマス・バイオ燃料開発に関す る社会影響評価のあり方提言

持続可能なバイオマス・バイオ燃料開発に関する社会 影響評価のあり方について，評価指標，評価方法，評 価範囲，評価条件など，評価の “あり方”に関する包 括的提言を行っている。評価結果を具体的な基準設定 や政策に適用するための定量評価までは行っていない。 類型 2 : 持続可能なバイオマス・バイオ燃料開発に関す る社会影響定量評価

持続可能なバイオマス・バイオ燃料開発に関する社会 影響評価について, 定量的評価指標の設定, 評価指標 の調査・計測, 評価指標の重み付け, 及び評価結果の 分析など，定量的かつ具体的な社会影響評価を行って いる。

類型 3 : 持続可能なバイオマス・バイオ燃料開発に関す る社会基準設定のあり方提言

持続可能なバイオマス・バイオ燃料開発に関する社会 基準について，その基準の項目や内容など基準設定の あり方に関する包括的提言を行っている。実際の基準 導入や認証にまでは至っていない。

類型 4 : 持続可能なバイオマス・バイオ燃料開発に関す る社会基準の導入検討

持続可能なバイオマス・バイオ燃料開発に関して, 設 定するべき社会基準の内容など，具体的な基準や政策 の項目について検討して抢り，その認証，もしくは実 際の導入にまで至っている。

以上の類型化に従い, 表 $1 \sim 2$ に示した事例の類型化 を行った結果を表 3 に示す。

持続可能なバイオマス・バイオ燃料開発に関する社会 影響評価結果を実際の基準設定などの政策や研究開発戦 略への適用を行う場合，バイオマス種類やバイオマスの 地域特性, 評価指標相互のトレードオフ関係, さらに基 準を導入する地域に扔ける各社会影響評価指標の重要性 に関する重み付けなども包括的に勘案する必要がある。 そのためには，上記バイオマス種類や地域特性を包括的 に勘案した定量的な社会影響評価結果が必要となるが, 


\section{表 3 事例の類型化に関する結果}

\begin{tabular}{|c|c|}
\hline 類型 & 事例組織名（国名） \\
\hline \multirow[t]{3}{*}{ 類型 1} & $\begin{array}{l}\text { RIRDC : Rural Industries Research and Development } \\
\text { Corporation（オーストラリア） }\end{array}$ \\
\hline & UN Energy \\
\hline & IEA-International Energy Agency Bioenergy Task29 \\
\hline \multirow[t]{4}{*}{ 類型 2} & Embrapa（ブラジル） \\
\hline & $\begin{array}{l}\text { SIBR : Socioeconomic Impacts of the Biofuels Revolu- } \\
\text { tion（米国） }\end{array}$ \\
\hline & Utrecht University（オランダ） \\
\hline & UNDP : United Nations Development Programme \\
\hline \multirow[t]{6}{*}{ 類型 3} & CEC : California Energy Commission（米国） \\
\hline & WWWF : World Wide Fund for Nature（ドイツ） \\
\hline & IBEP : International Bioenergy Platform \\
\hline & FAO : Food and Agriculture Organization \\
\hline & IEA-International Energy Agency Bioenergy Task40 \\
\hline & GBEP : G8 Global Bioenergy Partnership \\
\hline \multirow[t]{2}{*}{ 類型 4} & $\begin{array}{l}\text { RTFO : Renewable Transport Fuel Obligation（イギリ } \\
\text { ス) }\end{array}$ \\
\hline & RSPO : Roundtable on Sustainable Palm Oil \\
\hline
\end{tabular}

表 3 に示す通りこれまで行われた持続可能なバイオマス・ バイオ燃料開発に関する社会影響評価は地域やバイオマ ス種類が限定されている。したがって持続可能なバイオ マス・バイオ燃料開発に関する社会基準の検討を行うに は，その参考とするべき社会影響評価結果の事例数が圧 倒的に不足しており，社会影響評価結果の基準設定など 政策への適用を行っている事例は現段階では存在せず, 既存の世界基準を参考に具体的な基準の導入にまで至っ ている事例も僅であることが本論文における調査で明ら かとなった。

\section{3. 持続可能なバイオマス・バイオ燃料開発における社 会影響評価の課題}

本章では第 2 章の結果に基づき，持続可能なバイオマ ス・バイオ燃料開発に関する社会影響評価の課題につい て検討した結果を述べる。

\section{1 バイオマス種類や地域特性等に関する事例収集}

2.2で述べた通り，持続可能なバイオマス・バイオ燃料 開発に関する社会影響評価結果を実際の基準設定などの 政策や研究開発戦略への適用を行う場合，バイオマス種 類やバイオマスの地域特性, 評価指標相互のトレードオ フ関係，さらに基準を導入する地域における各社会影響 評価指標の重要性に関する重み付けなども包括的に勘案 した定量的な評価が重要となる。しかし本論文で記述し たオランダ，ブラジル，及びUNDPの事例からも分かる 通り，持続可能なバイオマス・バイオ燃料開発に関する 定量的な社会影響評価はステークホルダーへの質問形式 (アンケート方式)を基本としたフィールドワーク調査を
行なう必要があり，これら調査にバイオマス種類やバイ オマスの地域特性等も勘案する場合には膨大な資金と時 間が予想される。したがって，持続可能なバイオマス・バ イオ燃料開発に関する社会影響評価結果を実際の基準設 定などの政策や研究開発戦略へ適用するにはバイオマス 種類やバイオマスの地域特性等を勘案した定量的な評価 事例デー夕を可能な限り多く収集すると同時にケースス タディを実施し，それら限られた事例数から上述したよ うに多くのバイオマス種類やバイオマスの地域特性等に 対して汎用性のある結論を導出するための手法を検討す ることが重要な課題となる。

\section{2 定量的社会影響評価に向けた国際協力の促進}

3.1 で述べた通り，持続可能なバイオマス・バイオ燃料 開発に関する定量的な社会影響評価はステークホルダー への質問形式（アンケート方式）を基本としたフィール ドワーク調査を行なう必要があり，これら調査にバイオ マス種類やバイオマスの地域特性等も勘案する場合には 膨大な資金と時間が予想される。表 1 に示した国家・地 域単位の事例が先進国中心であること，さらに社会影響 評価結果が実際の基準設定などの政策や研究開発戦略へ 適用された例が存在しないことは，こうした資金面と時 間的な問題が大きな原因と考えられる。こうした資金面 や時間的な問題に対しては国際的対話や国際間の協力が 大きな効果を及ぼすと考えられ，実際にRSPOでの検討が 他の事例と比較して相対的に進展しているのはこれまで の地道な国際的枠組みにおける対話や活動が大きく影響 している。したがって，持続可能なバイオマス・バイオ 燃料開発に関するバイオマス種類やバイオマスの地域特 性等を勘案した定量的な社会影響評価に向けて，今後は 国際的対話や国際間の協力を促進することが重要な課題 となる。

\section{4. 結 論}

本論文では持続可能なバイオマス・バイオ燃料開発に おける社会影響評価についての現状と動向について調査 すると共に社会影響評価の（基準設定など）政策や研究 開発戦略への適用状況について分析を行った。その結果， 持続可能なバイオマス・バイオ燃料開発に関して定量的 かつ具体的な社会影響評価を行っている事例も僅かに存 在するものの，社会影響評価結果を基準設定など政策へ 適用している事例は現段階では存在せず，既存の世界基 準を参考に具体的な基準の導入にまで至っている事例も 僅であることが本論文における調査で明らかとなった。 また社会影響評価結果を実際の基準設定などの政策や研 究開発戦略への適用を行う場合，バイオマス種類やバイ オマスの地域特性，評価指標相互のトレードオフ関係，さ らに基準を導入する地域における各社会影響評価指標の 
重要性に関する重み付けなども包括的に勘案した定量的 な評価が重要となるが，そのためには定量的な評価事例 データの収集と汎用性のある結論導出手法の提案，及び 資金面や時間的な課題解決に向けた国際協力が重要であ ることを明らかにした。

現在，世界各国ではエネルギー安定確保，及び温室効 果ガス削減に向けたバイオマス及びバイオ燃料の導入を 促進しており，持続可能なバイオマス・バイオ燃料の開 発に向けた評価方法と基準の確立は早急に解決すべき課 題となっている。そのためには具体的な課題の内容を明 らかにすると同時に，それら課題解決に向けた方法論の 提案が今後のエネルギー政策策定，及び温暖化対策の検 討において重要となる。本論文における調査で明らかに した情報，及び指摘した課題の内容が今後のエネルギー 政策策定，及び温暖化対策検討を行う上で，その一助と なれば幸いである。

\section{文 献：References}

1）農林水産省HP：http://www.maff.go.jp/j/biomass/ index.html

2) 国連HP : http://www.un.org/esa/sustdev/

3) Commission on Sustainable Development, "CSD indicators of sustainable development- 3 rd edition”,(2007)

4) United Nation Energy, "Sustainable Bioenergy: A Framework for Decision Makers",(2007)

5) IEA Bioenergy ExCo54 Doc, "Task29 Socio-Economic Drivers in Implementing Bioenretgy Projects”,(2005)

6) van Dam, J., Junginger, M. et al, "Overview of recent developments in sustainable biomass certification”, IEA Bioenergy Task 40, (2006)

7) Nordin, M., "Sustainable Development Indicators Initia- tive in Malaysia-Novel Approaches and Viable Frameworks", LESTARI,(2001)

8）国際労働機関HP : http://www.ilo.org/global/lang--en/ index.htm

9) Rodrigues, G. S. et. al, Journal of Technology Management \& Innovation, 2(2), (2007)

10) Bolender, B. C. et. al, "Community Profile: Russel, Kansas",(2007)

11) California Energy Commission, "A Roadmap for the development of Biomass is California - Pier collaborative Report”, CEC-500-2006-095-D, (2006)

12) Smeets, E. et. al., "Sustainability of Brazilian bio-ethanol", UNICAMP Report NWS-E-2006-110,(2006)

13) Rural Industries Research and Development Corporation Publication No 05/190, "Sustainability guide for Bioenergy-A scoping study-",(2005)

14) Dehue, B., Hamelinck, C. et al, "Sustainability Reporting Within the RTFO: Framework Report”, ECOFYS, (2007)

15) Fritsche, U. R., Hunecke, K. et al, "Sustainability Standards for Bioenergy", WWWF Germany,(2006)

16) Food and Agriculture Organization of the United $\mathrm{Na}^{-}$ tions, "International Bioenergy Platform",(2006)

17) FAO HP : http//www.fao.org

18) United Nation Development Proglamme, "Environmental and Social Impact Analysis Stora Enso Plantation Project in Guangxi, China”,(2006)

19) Italian Ministry of the Environment and Territory, "The Global Bioenergy Partnership”,(2005)

20) Roundtable on Sustainable Palm Oil, "RSPO Principles and Criteria for Sustainable Palm Oil Production”,(2005) 